\title{
Association of factor V Leiden mutation with deep vein thrombosis among
}

\section{Egyptian cases}

\author{
"Sherif H. Abdeen, ${ }^{* *}$ Rizk El-Baz, "Wessam El-Gazar, ${ }^{* *}$ Ahmad Settin \\ *Zoology Department, Faculty of Science, Mansoura University \\ ${ }^{* *}$ Genetics Unit, Faculty of Medicine, Mansoura University
}

\begin{abstract}
Background: Deep vein thrombosis (DVT) is a blood clot in a major vein, usually in the legs and/or pelvis. If part of the thrombus breaks off, it becomes an embolism, which can travel through the heart and block the arteries to the lungs. Factor V Leiden (FVL) is a common genetic risk factor for hereditary hypercoagulability disorder in several populations. The present study investigates the association of FVL mutation with DVT among Egyptian cases.

Patients \& methods: The study included 44 cases (16 males and 28 females) with an age range of 20 to 80 years in addition to 211 healthy unrelated controls of matched age and sex. A multiplex allele-specific PCR amplification was conducted for assignment of FVL gene mutation (G1691A).

Results: Cases having the mutant allele A (AA and AG genotypes) were significantly higher than controls ( $38.6 \%$ vs. $18.5 \%$; $\mathrm{P}<0.05$, OR= 2.78 and CI $95 \%, 1.380-5.589$ ).

Conclusion: These results concluded that FVL mutation has a high frequency and positive association with the occurrence of deep vein thrombosis among Egyptian cases.
\end{abstract}

Keywords: factor V Leiden mutation, deep vein thrombosis, Egyptian population

\section{Introduction:}

Deep vein thrombosis (DVT) refers to a thrombus in the deep veins, most often in the lower extremities. The thrombus can embolize and become lodged in the pulmonary arteries, resulting in pulmonary embolism (PE). Deep venous thrombosis is a common disease with genetic and acquired risk factors. Acquired conditions that promote DVT include prolonged immobilization, major injuries and surgery. Hereditary coagulation defects associated with an increased risk of DVT are protein $\mathrm{C}$, protein $\mathrm{S}$, anti-thrombin deficiency, factor II (20210 G to A) mutation, activated protein $\mathrm{C}$ resistance, and factor $\mathrm{V}$ Leiden (FVL) mutation (Lane et al., 1996; Eekhoff et al., 2000; Michota, 2005).

Coagulation factor $\mathrm{V}(\mathrm{FV})$ is an important procoagulant protein, its activated form (FVa) is functioning as a cofactor in the generation of thrombin (Stormorken, 2003). FV is a single-chain mosaic domain structure composed of three homologous A-type domains, two smaller C-type domains and a large B-domain (A1A2-B-A3-C1-C2) (Nesheim et al., 1979; Jenny et al., 1987). Proteolytic activation of $\mathrm{FV}$ results in the removal of the FV Bdomain and the exposure of regions in the FV molecule that is important for the expression of its procoagulant activity (Steen and Dahlbak, 2002; Toso and Camire, 2004). The released $\mathrm{FVa}$ is composed of a $105 \mathrm{kDa}$ heavy chain (A1A2 domains) and a 74 to $71 \mathrm{kDa}$ light chain (A3-C1-C2 domains), held together by a single calcium ion and hydrophobic interactions (Nicolaes and Dahlback, 2002; Mann and Kalafatis, 2003). Besides circulating in free form in plasma, FV is also present in the granules of the platelets; this form accounts for about $25 \%$ of the total FV content in human blood (Chesney et al., 1981). During coagulation, platelet FV is secreted as a result of platelet activation. Although several cellular types 
have been reported to synthesize FV, it is generally accepted that the principal site of its biosynthesis is the liver, where human FV is synthesized as a single-chain molecule, undergoing extensive posttranslational modifications before being secreted into the blood (Owen and Bowie, 1977; Wilson et al., 1984).

The corresponding FV gene map on chromosome 1q23 is composed by 25 exons, spanning a chromosomal region of about $80 \mathrm{~kb}$. The encoded 2224 amino-acid pre-cofactor includes a 28-residues signal peptide (Nicolaes and Dahlback, 2002; Mann and Kalafatis, 2003; Duga et al., 2004). FV Leiden is currently the most common known genetic risk factor for the inherited thrombophilia. The factor $\mathrm{V}$ gene defect occurs in exon 10 where there is a GA substitution at nucleotide 1691 (Bertina et al., 1994). This mutation renders the factor $\mathrm{V}$ protein resistant to proteolytic inactivation by activated protein $\mathrm{C}$ and thus predisposes to thrombosis (Svensson and Dahlback, 1994).

The function of protein $\mathrm{C}$ is to inactivate factor Va and factor VIIIa (the 'a' denotes the active form). The first step in this process is the activation of thrombomodulin by thrombin. Subsequently, protein C combines with thrombomodulin in order to produce activated Protein C (Eisenberg et al., 1993). Activated protein $\mathrm{C}$ then combines with protein $\mathrm{S}$ on the surface of the platelets. Activated protein $\mathrm{C}$ can then degrade factor $\mathrm{Va}$ and factor VIIIa. When one has factor V Leiden, the factor $\mathrm{Va}$ is resistant to the normal effects of activated protein $\mathrm{C}$, thus the term activated protein $\mathrm{C}$ resistance. The result is that FVL is inactivated by activated protein $\mathrm{C}$ at a much slower rate, thus leading to a thrombophilic (propensity to clot) state by having increased activity of factor $\mathrm{V}$ in the blood (Hobikoglu et al., 2004).

Heterozygotes for FVL have an approximate eightfold increased relative risk for the development of venous thrombosis and homozygotes are estimated to have an approximately 90 -fold increased relative risk (Bertina, 1997). The mutation is also a risk factor for cerebral, mesenteric and portal vein thrombosis. There is evidence that FVL mutation, presumably due to thrombosis of placental vessels, may play a role in some cases of unexplained recurrent pregnancy loss (Preston et al., 1996; Ridker et al., 1998; Tormene et al., 1999; Martinelli et al., 2000; Stolz et al., 2000; Agaoglu et al., 2003; El-Karaksy et al., 2004).

From all of the previously mentioned literatures, it was therefore of interest to carry out experiments investigating the existence of FVL gene mutations and its association with hereditary thrombophilia among Egyptians.

\section{Patients and Methods:}

The patients included forty four (16 males and 28 females) suffering deep vein thrombosis (DVT), confirmed by ultrasonography. All clinical data are available at the Department of Surgery, Internal Medicine, Mansoura University Hospitals, Egypt. FVL genotypes and allele frequencies were compared to 211 healthy unrelated control cases of matched age and sex from the same locality. After obtaining informed consent from all cases and controls, $3 \mathrm{ml}$ venous blood sample were collected from each subject for DNA extraction and purification (Gentra systems, USA). FVL gene mutation (G1691A) was detected using a multiplex allele-specific PCR amplification for both FVL gene and factor IX as an internal control. Each PCR was performed with $300 \mathrm{ng}$ of DNA, 200 $\mathrm{mmol} / \mathrm{L}$ of each dNTP, $500 \mathrm{mmol} / \mathrm{L}$ of each primer, and 2.5 units of Taq DNA polymerase (Amplitaq Gold, Perkin-Elmer Cetus, Norwalk, Conn). DNA was initially denatured for 10 minutes at $95^{\circ} \mathrm{C}$, and then 10 cycles were performed as follows: $94^{\circ} \mathrm{C}$ for 30 seconds, $60^{\circ} \mathrm{C}$ for 30 seconds, and $72^{\circ} \mathrm{C}$ for 1 minute. Then, 25 cycles were performed as follows: $94^{\circ} \mathrm{C}$ for 30 seconds, $55^{\circ} \mathrm{C}$ for 30 seconds, and $72^{\circ} \mathrm{C}$ for 1 minute. The PCR amplification was completed by a final extension at $72^{\circ} \mathrm{C}$ for 7 minutes. Amplification of the factor $\mathrm{V}$ gene 
resulted in 152 base pair (bp) product while the internal amplification control (factor IX gene) resulted in a $250 \mathrm{bp}$ product. The amplified products were then electrophoresed in $2 \%$ agarose gel, stained with ethidium bromide, and visualized under UV light. The primers were designed following Hezard et al. (1998) and Ranguelov et al. (2002) and their sequences were as follows:

FV common 5', GGA CTA CTT

GAC AATTAC TGT TCT CTT G 3'.

FV WT (wild type) 5'- GCA GAT

CCC TGG ACA GAC G 3'.

FV MT (mutant type) 5' - GCA GAT

CCC TGG ACA GAC A3'.

FIX-1 5'- CTC CTG CAG CAT

TGA GGGAGA TGG ACA TT 3'.

FIX-2 5'- CTC GAA TTCGGC

AAG CAT ACT CAA TGT AT 3'

\section{Statistical analysis}

Data were analyzed using SPSS statistical package software for calculation of genotype and allele frequencies. Testing association and risk related to FVL and DVT was done by comparing genotype and allele frequencies in cases and controls using Fisher's exact test for continuity correction together with odds ratio (OR) and $95 \%$ confidence intervals. Moreover, Hardy-Weinberg test was applied on genotype and allele frequencies of controls to check for significance of difference between observed and expected genotype frequencies and found non-significant using Chi Square test.

\section{Results:}

The present study included 44 patients suffering DVT. The patients included 16 (36.4\%) males and 28 (63.6\%) females, all in the age range of 20-80 years. Another 211 healthy individuals, with no history of any vein thrombosis diseases, were also included as controls. The age and sex of the control group were approximately similar to those of the patients.

The total cases showed nonsignificant frequency of the FVL heterozygous mutant genotype GA among
DVT cases $(27.3 \%)$ compared with that of the controls $(16.6 \%),(\mathrm{P}>0.05, \mathrm{OR}=1.886$ and CI (95\%, 0.8851-4.017). The total cases showed a significant higher frequency of the homozygous mutant genotype AA among the patients group $(11.4 \%)$ compared with that of the controls $(1.9 \%)$, $(\mathrm{P}<0.01, \mathrm{OR}=6.635$ and $\mathrm{CI}(95 \%, 1.705-$ 25.821).

Therefore, the total cases showed a highly significant frequency of the total FVL mutant genotypes AA and GA (homozygous \& heterozygous, respectively) among DVT cases (38.6\%) compared with that of the controls $(18.5 \%)$, $(\mathrm{P}<0.0001, \mathrm{OR}=2.777$ and $\mathrm{CI}(95 \%$, 1.380-5.589). Regarding allelic frequencies, the mutant $\mathrm{A}$ allele was in $22(25 \%)$ cases and 43(10.19\%) controls (P $<0.01, \mathrm{OR}=2.938$ and $\mathrm{CI}(95 \%, 1.651-$ 5.229). On the other hand, the normal $\mathrm{G}$ allele was in $66(75 \%)$ cases and 379 $(89.81 \%)$ controls $(\mathrm{P}<0.01, \mathrm{OR}=0.3404$ and CI (95\%, 0.1912-0.6058; Table 1, Fig. $1)$.

\section{Discussion:}

The Leiden mutation of blood coagulation factor $\mathrm{V}$ could be considered the commonest genetic abnormality associated with venous thromboembolism (Bertina et al., 1994). There are several reports elaborating the fact that Factor V Leiden is a well established risk factor for deep vein thrombosis in several populations (Folsom et al., 2002; Bouaziz-Borgi et al., 2006; Biswas et al., 2008).

In Tunisian population, it was found that FVL genotypes were present at higher frequencies in DVT patients, and increased prevalence of single mutant (1691A/4070G and $1691 \mathrm{G} / 4070 \mathrm{~A})$, but not double mutant (1691A/4070A) haplotypes were seen among DVT patients (Bouaziz-Borgi et al., 2007).

In USA, a study based on 4047 American men and women found that a $12 \%$ incidence of heterozygosity for the FVL mutation with DVT or pulmonary embolism compared with $6 \%$ in controls (Ridker et al., 1997). In Switzerland, another study showed that FVL heterozygotes had a nearly eightfold lower 
incidence of DVT involving the iliofemoral veins and significantly fewer extensive thromboses compared to individuals without the mutation (de Moerloose et al., 2000). In Germanium population isolated DVT was also the most common major thrombotic event in a large cohort of FVL homozygotes (Ehrenforth et al., 2004). In Italian population several earlier studies were suggested that individuals heterozygous for FVL had a two- to fourfold increased risk of recurrent thrombosis (Simioni et al., 1997; 2000), although other studies in Austrian, Italian and Sweden population found no significant increase in risk (Eichinger et al., 1997; De Stefano et al., 1999; Lindmarker et al., 1999).

The present study showed a significant higher frequency of the homozygous mutant genotype AA among the patient group (11.4\%) compared with that of the controls $(1.9 \%),(\mathrm{OR}=6.635, \mathrm{P}<$ $0.05)$. The total cases showed non significant higher frequency of the factor $\mathrm{V}$ Leiden heterozygous mutant genotype GA among DVT cases $(27.3 \%)$ compared with that of the controls $(16.6 \%),(\mathrm{OR}=1.886, \mathrm{P}$ $>0.05$ ). Combining both heterozygous and homozygous genotype frequency of FVL mutation i.e. all allele A carriers (AA+GA), cases showed an extremely significant higher frequency of both genotypes compared with that of the controls $(38.6 \%$ vs. $18.5 \%, \mathrm{OR}=2.777, \mathrm{P}<0.0001)$. Regarding allelic frequencies, the mutant A allele was $22(25 \%)$ in cases and 43 $(10.19 \%)$ in controls $(\mathrm{OR}=2.938, \mathrm{P}<$ $0.01)$. On the other hand, the normal $G$ allele was $66(75 \%)$ in cases and 379 $(89.81 \%)$ in controls $(\mathrm{OR}=0.3404, \mathrm{P}<$ $0.01)$.

These results may indicate that thrombophilia due to the presence of the FVL mutation is relatively high in Egyptian DVT patients as well. Moreover, there was no statistical significant difference between cases subgroups such as cases with age > 50 years vs. cases $<50$ years, male cases vs. female cases, anemic cases vs. nonanemic cases, high oedema vs. cases low oedema, high platelet cases vs. low platelet and cases with high prothrombin ratio vs. with low prothrombin ratio, all with positivity for mutant FVL mutation (GA + AA).

Interestingly, frequencies of FVL mutation among Egyptian deep vein thrombosis cases and controls were higher than that reported in other Mediterranean countries as well as Western countries as evidenced from the later-mentioned studies.

In Kurdish population, it has been reported that the prevalence of FVL among healthy individuals of Kurdish ethnic background in Western Iran. Factor V G1691A mutation was detected as heterozygous in 11 of 404 healthy individuals (five female and six male) and as homozygous in one male indicating a prevalence of $2.97 \%$ (95\% CI, 1.3-4.6) and allele frequency of $1.6 \%$. This indicated that the FVL is not rare among populations of Western Iran (Rahimi et al., 2008).

Also in Asian-Indian population, it has been confirmed that FVL mutation was significantly associated with the risk of DVT. FVL was seen in 16 out of 155 patients (10.3\%). Thirty-one of patients showed activated protein $\mathrm{C}$ resistance of which only 16 carried FVL mutation which was a far lower number than what is usually seen in Caucasian population. Of the 16 patients, $4(2.58 \%)$ were homozygous for the mutant type and the rest i.e., 12 (7.72\%) were heterozygous. Only one of the healthy controls was heterozygous for FVL ( $\mathrm{P}<$ 0.01, 95\% CI; OR: 13.7; Biswas et al., 2008).

In Netherlands Dutch population, there was a high prevalence of inherited thrombophilia as manifested by the presence of FVL with few acquired risk factors for thrombosis. It has been found that the synergy index between minor events (short periods of immobilization such as prolonged travel, short illness, minor surgery or injuries) and FVL mutation in the case-only analysis was 0.7 (95\% CI, OD: 0.3-1.5). Therefore, persons with FVL mutation who experience a minor event will have an estimated risk increase of about 17-fold, which exceeds the sum of the individual risk factors (Eekhoff et al., 2000).

In Macedonian population, it has been found that FVL carriers have the highest odds of developing DVT; $21.1 \%$ 
(95\% CI, 14.3-25.7), compared with 5.5\% in the healthy individuals (Arsov et al., 2006).

In Arab communities, it has been found that FVL was a common genetic risk factor for DVT in both communities Lebanon and Tunisia. Subjects comprised 198 DVT patients and 540 healthy controls from Lebanon and 126 Tunisian DVT patients and 197 control subjects; FVL (MnlI) genotyping was done by PCRRFLP.The prevalence of FVL mutant A allele and the G/A and A/A genotypes were significantly higher among DVT patients from Lebanon and Tunisia (BouazizBorgiet al., 2007).

In American population, it has been reported that the incidence of abnormality in patients with DVT was $27 / 44(61 \%$; $95 \%$ CI $47-76 \%)$ and 10 of these patients were positive for FVL (23\%; 95\% CI, $10-35 \%$; Caprini et al., 2005).

On the other hand, in the Chinese population it has been shown that FVL is very rare, through study on 178 patients with DVT and 102 control subjects (Jun et al., 2006).

In conclusion, the present study may help for better understanding for the hereditary causes of thrombophilia in Egyptian population.

\section{References:}

Agaoglu N, Mustafa NA, Türkyilmaz S. (2003). Prothrombotic disorders in patients with mesenteric vein thrombosis. J Invest Surg. 16(5):299-304.

Arsov T, Miladinova D, Spiroski M. (2006) Factor V Leiden is associated with higher risk of deep venous thrombosis of large blood vessels. Croat Med J. 47(3):433-9.

Bertina RM. (1997). Factor V Leiden and other coagulation factor mutations affecting thrombotic risk. Clin Chem. 43(9):1678-83.

Bertina RM, Koeleman BP, Koster T, Rosendaal FR, Dirven RJ, de Ronde H, van der Velden PA, Reitsma PH. (1994). Mutation in blood coagulation factor $\mathrm{V}$ associated with resistance to activated protein C. Nature. 369(6475):64-7.

Biswas A, Bajaj J, Ranjan R, Meena A, Akhter MS, Yadav BK, Sharma V, Saxena R. (2008).
Factor V Leiden: is it the chief contributor to activated protein $\mathrm{C}$ resistance in Asian-Indian patients with deep vein thrombosis? Clin Chim Acta. 392(1-2):21-4.

Bouaziz-Borgi L, Almawi WY, Mtiraoui N, Nsiri B, Keleshian SH, Kreidy R, Louzir B, Hezard N, Mahjoub T. (2006). Distinct association of factor $\mathrm{V}$-Leiden and prothrombin G20210A mutations with deep venous thrombosis in Tunisia and Lebanon. Am J Hematol. 81(8):641-3.

Bouaziz-Borgi L, Nguyen P, Hezard N, Musharrafieh U, Almawi WY, Mahjoub T. (2007). A case control study of deep venous thrombosis in relation to factor V G1691A (Leiden) and A4070G (HR2 Haplotype) polymorphisms. Exp Mol Pathol. 83(3):480-3.

Caprini JA, Goldshteyn S, Glase CJ, Hathaway K. (2005). Thrombophilia testing in patients with venous thrombosis. Eur J Vasc Endovasc Surg. 30(5):550-5.

Chesney CM, Pifer D, Colman RW. (1981). Subcellular localization and secretion of factor V from human platelets. Proc Natl Acad Sci U S A. 78(8):5180-4.

de Moerloose P, Reber G, Perrier A, Perneger T, Bounameaux H. (2000). Prevalence of factor V Leiden and prothrombin G20210A mutations in unselected patients with venous thromboembolism. Br J Haematol. 110(1):1259.

De Stefano V, Martinelli I, Mannucci PM, Paciaroni K, Chiusolo P, Casorelli I, Rossi E, Leone G. (1999). The risk of recurrent deep venous thrombosis among heterozygous carriers of both factor $\mathrm{V}$ Leiden and the G20210A prothrombin mutation. $\mathrm{N}$ Engl $\mathrm{J}$ Med. 341(11):801-6.

Duga S, Asselta R, Tenchini ML. (2004). Coagulation factor V. Int J Biochem Cell Biol. 36(8):1393-9.

Eekhoff EM, Rosendaal FR, Vandenbroucke JP. (2000). Minor events and the risk of deep venous thrombosis. Thromb Haemost. 83(3):408-11.

Ehrenforth S, Nemes L, Mannhalter C, Rosendaal FR, Koder S, Zoghlami-Rintelen C, Scharrer I, Pabinger I. (2004). Impact of environmental and hereditary risk factors on the clinical manifestation of thrombophilia in homozygous carriers of factor V:G1691A. J Thromb Haemost. 2(3):430-6. 
Eichinger S, Pabinger I, Stümpflen A, Hirschl M, Bialonczyk C, Schneider B, Mannhalter C, Minar E, Lechner K, Kyrle PA. (1997). The risk of recurrent venous thromboembolism in patients with and without factor $\mathrm{V}$ Leiden. Thromb Haemost. 77(4):624-8.

Eisenberg PR, Siegel JE, Abendschein DR, Miletich JP. (1993). Importance of factor Xa in determining the procoagulant activity of whole-blood clots. J Clin Invest. 91(5):187783.

El-Karaksy H, El-Koofy N, El-Hawary M, Mostafa A, Aziz M, El-Shabrawi M, Mohsen NA, Kotb M, El-Raziky M, ElSonoon MA, A-Kader H. (2004). Prevalence of factor $\mathrm{V}$ Leiden mutation and other hereditary thrombophilic factors in Egyptian children with portal vein thrombosis: results of a single-center case-control study. Ann Hematol. 83(11):712-5. Erratum in: Ann Hematol. 84(3):205.

Folsom AR, Cushman M, Tsai MY, Aleksic N, Heckbert SR, Boland LL, Tsai AW, Yanez ND, Rosamond WD. (2002). A prospective study of venous thromboembolism in relation to factor $\mathrm{V}$ Leiden and related factors. Blood. 99(8):2720-5.

Hezard N, Cornillet-Lefebvre P, Gillot L, Potron G, Nguyen P. (1998). Multiplex ASA PCR for a simultaneous determination of factor V Leiden gene, G-->A 20210 prothrombin gene and C-->T 677 MTHFR gene mutations. Thromb Haemost. 79(5):1054-5.

Hobikoglu GF, Akyuz U, Akyuz F, Ozer O, Güney D, Narin A, Unaltuna N. (2004). Factor V leiden is a risk factor for myocardial infarction in young Turkish men. Acta Cardiol. 59(6):594-7.

Jenny RJ, Pittman DD, Toole JJ, Kriz RW, Aldape RA, Hewick RM, Kaufman RJ, Mann KG. (1987). Complete cDNA and derived amino acid sequence of human factor V. Proc Natl Acad Sci U S A. 84(14):4846-50.

Jun ZJ, Ping T, Lei Y, Li L, Ming SY, Jing W. (2006). Prevalence of factor V Leiden and prothrombin G20210A mutations in Chinese patients with deep venous thrombosis and pulmonary embolism. Clin Lab Haematol. 28(2):111-6.
Lane DA, Mannucci PM, Bauer KA, Bertina RM, Bochkov NP, Boulyjenkov V, Chandy M, Dahlbäck B, Ginter EK, Miletich JP, Rosendaal FR, Seligsohn U. (1996). Inherited thrombophilia: Part 2. Thromb Haemost. 76(6):824-34. Erratum in: Thromb Haemost 77(5): 1047.

Lindmarker P, Schulman S, Sten-Linder M, Wiman B, Egberg N, Johnsson H. (1999). The risk of recurrent venous thromboembolism in carriers and non-carriers of the G1691A allele in the coagulation factor $\mathrm{V}$ gene and the G20210A allele in the prothrombin gene. DURAC Trial Study Group. Duration of Anticoagulation. Thromb Haemost. 81(5):684-9.

Mann KG, Kalafatis M. (2003). Factor V: a combination of Dr Jekyll and Mr Hyde. Blood. 101(1):20-30.

Martinelli I, Taioli E, Cetin I, Marinoni A, Gerosa S, Villa MV, Bozzo M, Mannucci PM. (2000). Mutations in coagulation factors in women with unexplained late fetal loss. N Engl J Med. 343(14):1015-8

Michota F. (2005). Venous thromboembolism: epidemiology, characteristics, and consequences. Clin Cornerstone. 7(4):8-15.

Nesheim ME, Taswell JB, Mann KG. (1979). The contribution of bovine Factor $\mathrm{V}$ and Factor $\mathrm{Va}$ to the activity of prothrombinase. J Biol Chem. 254(21):10952-62.

Nicolaes GA, Dahlbäck B. (2002). Factor V and thrombotic disease: description of a janus-faced protein. Arterioscler Thromb Vasc Biol. 22(4):530-8.

Owen CA Jr, Bowie EJ. (1977). Generation of coagulation factors $\mathrm{V}, \mathrm{XI}$, and XII by the isolated rat liver. Haemostasis. 6(4):205-12.

Preston FE, Rosendaal FR, Walker ID, Briët E, Berntorp E, Conard J, Fontcuberta J, Makris M, Mariani G, Noteboom W, Pabinger I, Legnani C, Scharrer I, Schulman S, van der Meer FJ. (1996). Increased fetal loss in women with heritable thrombophilia. Lancet. 348(9032):9136.

Rahimi Z, Vaisi-Raygani A, Mozafari H, Kharrazi H, Rezaei M, Nagel RL. (2008). Prevalence of factor V Leiden (G1691A) and prothrombin (G20210A) among Kurdish population from Western Iran. J Thromb Thrombolysis. 25(3):280-3.

Ranguelov RD, Rosenthal N, Bromley C, Vasef MA.

(2002). 
Detection of factor $\mathrm{V}$ leiden and prothrombin gene mutations in patients who died with thrombotic events. Arch Pathol Lab Med. 126(10):1193-6.

Ridker PM, Miletich JP, Buring JE, Ariyo AA, Price DT, Manson JE, Hill JA. (1998). Factor V Leiden mutation as a risk factor for recurrent pregnancy loss. Ann Intern Med. 128(12 Pt 1):1000-3.

Ridker PM, Miletich JP, Hennekens CH, Buring JE. (1997). Ethnic distribution of factor V Leiden in 4047 men and women. Implications for venous thromboembolism screening. JAMA. 277(16):1305-7.

Simioni P, Prandoni P, Lensing AW, Manfrin D, Tormene D, Gavasso S, Girolami B, Sardella C, Prins M, Girolami A. (2000). Risk for subsequent venous thromboembolic complications in carriers of the prothrombin or the factor $\mathrm{V}$ gene mutation with a first episode of deep-vein thrombosis. Blood. 96(10):332933.

Simioni P, Prandoni P, Lensing AW, Scudeller A, Sardella C, Prins MH, Villalta S, Dazzi F, Girolami A. (1997). The risk of recurrent venous thromboembolism in patients with an Arg506-->Gln mutation in the gene for factor V (factor V Leiden). N Engl J Med. 336(6):399403.
Steen M, Dahlback B. (2002). Thrombinmediated proteolysis of factor $\mathrm{V}$ resulting in gradual B-domain release and exposure of the factor Xa-binding site. J Biol Chem. 277(41):38424-30.

Stolz E, Kemkes-Matthes B, Pötzsch B, Hahn M, Kraus J, Wirbartz A, Kaps M. (2000). Screening for thrombophilic risk factors among 25 German patients with cerebral venous thrombosis. Acta Neurol Scand. 102(1):31-6.

Stormorken H. (2003). The discovery of factor $\mathrm{V}$ : a tricky clotting factor. J Thromb Haemost. 1(2):206-13.

Svensson PJ, Dahlback B. (1994). Resistance to activated protein $\mathrm{C}$ as a basis for venous thrombosis. N Engl J Med. 330(8):517-22.

Tormene D, Simioni P, Prandoni P, Luni S, Innella B, Sabbion P, Girolami A. (1999). The risk of fetal loss in family members of probands with factor V Leiden mutation. Thromb Haemost. 82(4):1237-9.

Toso R, Camire RM. (2004). Removal of Bdomain sequences from factor $\mathrm{V}$ rather than specific proteolysis underlies the mechanism by which cofactor function is realized. $\mathrm{J}$ Biol Chem. 279(20):21643-50.

Wilson DB, Salem HH, Mruk JS, Maruyama I, Majerus PW. (1984). Biosynthesis of coagulation Factor V by a human hepatocellular carcinoma cell line. J Clin Invest. 73(3):654-8. 


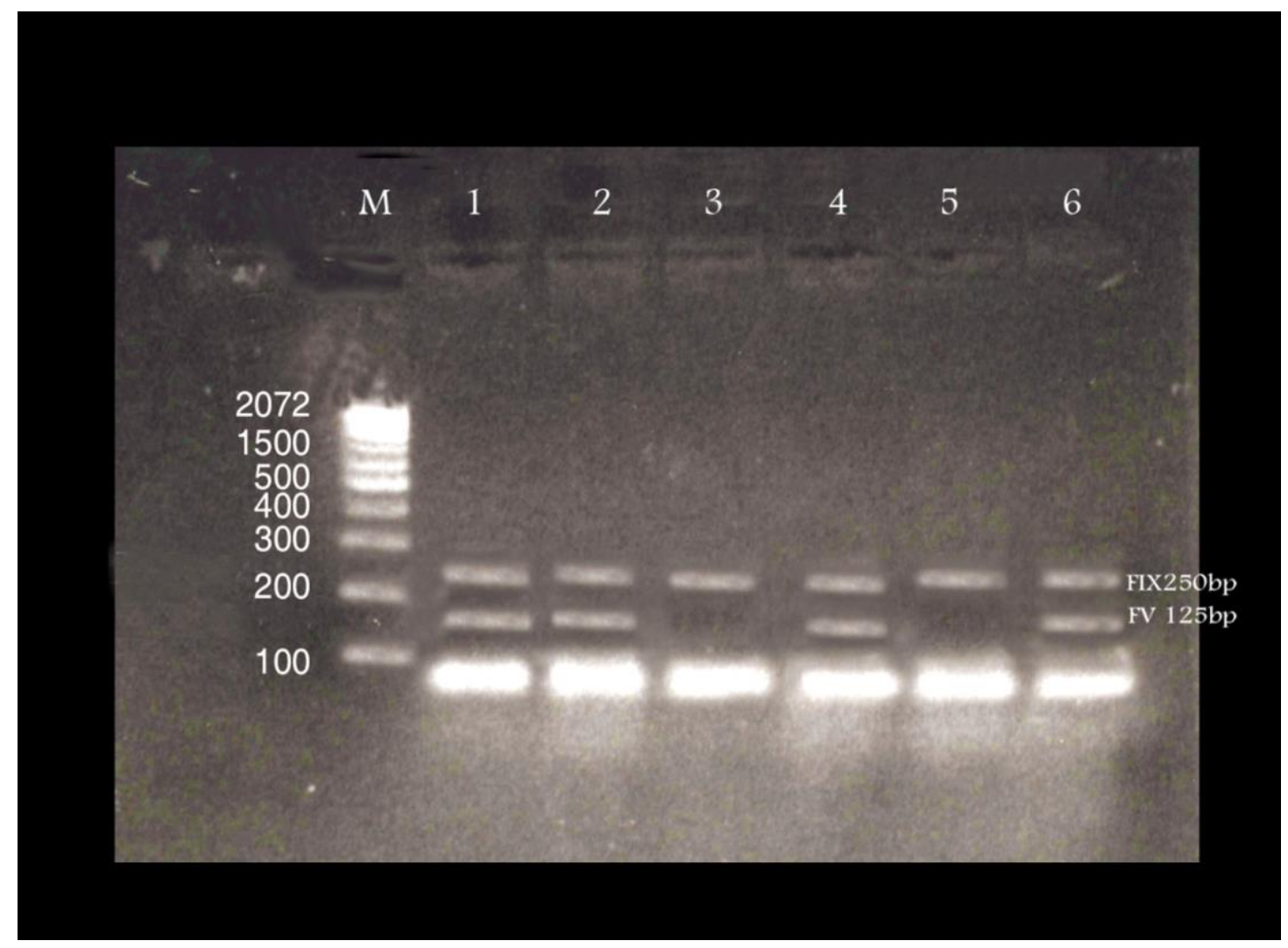

Figure 1. Amplification of factor V Leiden (FVL) using primers for mutant A alleles (lanes 1, 3, 5) and normal $\mathrm{G}$ allele (lanes 2, 4, 6) showing positive bands (125 bp) in lane 1, 2, 4, 6 with negative bands in lanes 3, 5 indicating G/A heterozygous genotype in case 1 (lanes 1,2) and G/G normal genotype in cases 2, 3 (lanes 3, 4, 5, 6). M indicates molecular marker, Bands of size $250 \mathrm{bp}$ belongs to FIX used as internal controls. 
Table 1. Frequency of factor V Leiden mutation among deep vein thrombosis cases compared to controls.

\begin{tabular}{|c|c|c|c|c|}
\hline Genotype & $\begin{array}{c}\text { Total Cases } \\
\text { N (\%) }\end{array}$ & $\begin{array}{r}\text { Control } \\
\text { N (\%) }\end{array}$ & P-value & $\begin{array}{c}\text { OR } \\
(95 \% \text { CI })\end{array}$ \\
\hline \multicolumn{5}{|c|}{ Individual genotype frequency } \\
\hline Total & $44(100)$ & $211(100)$ & & \\
\hline GG & $27(61.3 \%)$ & $172(81.5)$ & P < $0.01^{* *}$ & $0.360(0.1789-0.7248)$ \\
\hline GA & $12(27.3 \%)$ & $35(16.6)$ & P > 0.05 & $1.89(0.8851-4.017)$ \\
\hline AA & $5(11.4 \%)$ & $4(1.9)$ & P < $0.01^{* *}$ & $6.64(1.705-25.821)$ \\
\hline \multicolumn{5}{|c|}{ Total homozygous mutant \& heterozygous } \\
\hline AA + GA & $17 / 44(38.6 \%)$ & $39(18.5)$ & P < $0.01^{* *}$ & $2.78(1.380-5.589)$ \\
\hline \multicolumn{5}{|c|}{ Individual allele frequency } \\
\hline A & $22 / 88(25 \%)$ & $43(10.19)$ & P < $0.001^{* * *}$ & $2.94(1.651-5.229)$ \\
\hline G & $66 / 88(75 \%)$ & $379(89.81)$ & P < $0.001^{* * *}$ & $0.34(0.1912-0.6058)$ \\
\hline
\end{tabular}

${ }^{* * *} \mathrm{P}<0.01$ highly significant

${ }^{* * * *} \mathrm{P}<0.001$ very highly significant

P: probability, OR: odds ratio, $\mathrm{CI}$ : confidence intervals and $\mathrm{N}=$ number of cases

GG homozygous wild type, GA heterozygous, AA homozygous mutant 



\section{ارتباط طقرة العامل الخامس لايدن بالانسداد الوريدى العميق بين حالات مصرية}

$$
\begin{aligned}
& \text { *شريف حلمى عابدين ، **رزق الباز ، *وسام الجزار ، **أحمد ستين }
\end{aligned}
$$

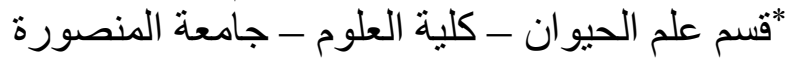

$$
\begin{aligned}
& \text { *وحدة الور اثة ـ كلية الطب - جامعة المنصورة المنصوة }
\end{aligned}
$$

الخلفية: يعتبر الانسداد الوريدى العميق تجلطاً للام فى وريد رئيسى ، عادة فى الأرجل أو فى ألى

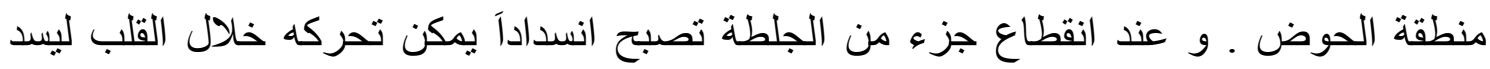
شر اين الرئة. يعتبر العامل الخامس لايدن عامل وراثى خطير لاضطر اب زيادة التجلط المورث فى

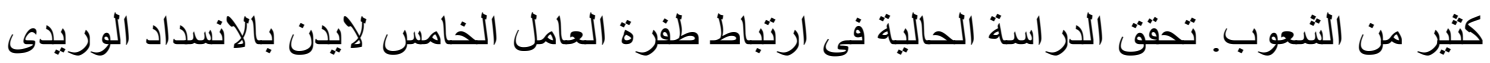
العميق بين حالات مصرية.

الحلات و الطرق: تتضمن الدراسة 44 حالة (16 ذكر و 28 انثى) بمدى عمرى من 20 الى ثمانين عاماً بالاضافة الى 211 شخص أصحاء كمجموعة ضابطة بعمر و جنس متو افق. تم استخدام افاضة ال DNA بتفاعل البلمرة المنسلسل الخاص بالصورة الجينية للكثف عن الطفرة الجينية للعامل الخامس لايدن (G1691A) .

النتائج: أظهرت الحالات الصورة الجينية المتطفرة A (طرز جينية AA و AG) أكثر بصورة ذات دلالة عن المجموعة الضابطة $38.6 \%$ vs. 18.5\%; P > 0.05, OR= 2.78 and CI

$$
\text { .95\%, 1.380-5.589) }
$$

الاستتتاج: تنتهى النتائج الى أن طفرة العامل الخامس لايدن تتكرر بصورة عالية و ترتبط ارتباطاً ايجابياً بظهور الانسداد الوريدى العميق بين الحالات المصرية. 